\title{
COMPARISON OF BICONDYLAR TIBIAL PLATEAU FRACTURES WITH DOUBLE OR SINGLE LATERAL LOCKED PLATE
}

\author{
COMPARAÇÃO DE FRATURAS DO PLANALTO TIBIAL BICONDILAR \\ COM DUPLA PLACA OU PLACA BLOQUEADA LATERAL ÚNICA
}

\author{
Matheus Manolo arouca ${ }^{1}$ (i), Guilherme Henrique Ricardo da $\operatorname{Costa}^{1}$ (i), Marcos Camargo Leonhardi $^{1}$ (i), \\ DENNIS BARBOSA ${ }^{1}$ [D, JORGE DOS SANTOS SILVA ${ }^{1}$ [1], KODI EDSON KOJIMA ${ }^{1}$ (1)
}

1. Universidade de São Paulo, Medical School, Institute of Orthopedics and Traumatology, São Paulo, SP, Brazil.

\section{ABSTRACT}

Objective: To compare postoperative radiographic outcomes of Schatzker type $\mathrm{V}$ and VI tibial plateau fractures treated with double-plate or single lateral locked plate. Methods: Sixty-three patients operated from December 2011 to February 2016 were selected, 47 from the double-plate group and 16 from the single lateral locked plate group. Minimum follow-up for all patients was 6 months. Fracture reduction evaluation was based on radiographic parameters: joint reduction, sagittal alignment, coronal alignment, and condylar width. Results: Radiographic evaluation showed no statistical difference in the immediate or late postoperative periods. Conclusion: Despite the reduced sample, this study is aligned with current results published in the medical literature. The severity of Schatzker type V and VI tibial plateau fractures can be minimized by the correct indication for the implant regarding fracture morphology. Level of Evidence III, Retrospective comparative study.

Keywords: Tibial Fractures. Fracture Fixation, Internal. Orthopedic Fixation Devices.

\section{RESUMO}

Objetivo: Comparar desfechos radiográficos pós-operatórios de fraturas do planalto tibial Schatzker V e VI tratados com dupla placa ou placa bloqueada única lateral. Métodos: Foram selecionados 63 pacientes operados no período de dezembro de 2011 a fevereiro de 2016, sendo 47 do grupo dupla placa e 16 do grupo placa bloqueada lateral única. Todos os pacientes tiveram seguimento mínimo de seis meses. A avaliação da redução das fraturas foi baseada nos parâmetros radiográficos: redução articular, alinhamento sagital, alinhamento coronal e largura condilar. Resultados: A avaliação radiográfica não demonstrou diferença estatística no pós-operatório imediato nem no tardio. Conclusão: Apesar da amostra reduzida, o estudo vai ao encontro dos resultados mais atuais publicados na literatura médica. A gravidade das fraturas do planalto tibial Shatzker V e VI pode ser minimizada com a correta indicação do implante segundo a morfologia da fratura. Nível de Evidência III, Estudo retrospectivo comparativo.

Descritores: Fraturas da Tíbia. Fixação Interna de Fraturas. Dispositivos de Fixação Ortopédica.

Citation: Arouca MM, Costa GHR, Leonhardt MC, Barbosa D; Silva JS, Kojima KE. Comparison of bicondylar tibial plateau fractures with double or single lateral locked plate. Acta Ortop Bras. [online]. 2020;28(4):182-5. Available from URL: http://www.scielo.br/aob.

\section{INTRODUCTION}

Tibial plateau fractures account for 1 to $2 \%$ of all fractures and approximately $8 \%$ of fractures in the elderly, according to data from international literature. They have a bimodal distribution, affecting elderly over 60 years old in a mild pattern, due to falls at the same level, and young adults in more severe patterns, involving traffic trauma or fall from great-heights. ${ }^{1}$ The management of high-energy tibial plateau fractures, characterized by joint comminution, meta-diaphyseal disjunction and soft tissue injury, ${ }^{2}$ remains challenging. Fractures that involve the two plateaus, medial and lateral, are called bicondylar. According to the most frequently used classification system, these lesions are framed as Schatzker V and VI; or Type $\mathrm{C}$ as per the AO/OTA CLASSIFICATION (Arbeitsgemeinschaft für Osteosynthesefragen / Orthopaedic Trauma Association). ${ }^{2,3}$
Bicondylar tibial plateau fractures are treated with techniques that stabilize both the medial and lateral columns, to reconstruct the articular surface and prevent varus collapse resulting from medial column failure. Initially, surgical procedures were performed by a single anterior incision. Both the medial and lateral plates were inserted by this route. However, double-route technique with tibial fixation spread out, using the medial and lateral support plates with conventional implants. For presenting less complications, this technique was established as the gold standard. ${ }^{4}$ Yet, the incidence of soft tissue-related complications is still meaningful.

Recently, the use of anatomical lateral locked plates has been an advance for the treatment of bicondylar tibial plateau fractures. Single lateral incision improves soft tissue preservation, reduces surgical time, and favors the outcomes. ${ }^{5-8}$ However, the literature

All authors declare no potential conflict of interest related to this article.

The study was conducted at Universidade de São Paulo, Medical School, Hospital das Clínicas, Institute of Orthopedics and Traumatology.

Correspondence: Matheus Manolo Arouca. Rua Oscar Freire, 1753, ap 21B, São Paulo, SP, Brazil, 05409-011. matheus.m.arouca@gmail.com

Article received on 01/17/2020, approved on 02/10/2020. 
both corroborates and contradicts this perspective. ${ }^{9-12}$ Among others, tibial fixation using lateral locked plate causes the highest rates of loss of reduction, vicious consolidation and complaints related to the synthesis material. 9,10,12 Furthermore, other studies showed no significant difference of infectious character between the surgical methods, nor in surgical and hospitalization periods. ${ }^{9}$ Thus, this study aims to demonstrate that the single lateral locked plate should be considered in the osteosynthesis of Schatzker type $\mathrm{V}$ and $\mathrm{VI}$ tibial plateau fractures.

\section{MATERIALS AND METHODS}

The study identified and evaluated, in a retrospective and non-randomized way, adults with Schatzker type V and VI tibial plateau fractures submitted to internal fixation using double or lateral single locked plate in the proximal region of the tibia. In total, 89 patients operated from December 2011 to February 2016 were selected. This study was approved by the Ethics Committee, registered in Plataforma Brasil, under the CAAE No: 75439717.4.0000.0068.

The study included patients with Schatzker type $\mathrm{V}$ and VI tibial plateau fracture at any age, who agreed to participate in the study by signing the informed consent form.

Exclusion criteria were: the presence of other fractures or associated neurovascular injuries, bilateral tibial plateau fracture, fracture progression over 30 days, pathological fractures, fractures with no clinical indication for the procedure, lack of adequate radiographic documentation for evaluation, and refusal to sign the informed consent form. After applying the inclusion and exclusion criteria, 63 patients were selected.

Patients' medical records were evaluated to collect demographic data and mechanism of injury, and determine time and type of fracture, type of internal fixation and associated lesions.

Minimum follow-up for all patients was 6 months. Anteroposterior radiographs and affected knee profile were performed in the immediate postoperative period and after 6 months. To evaluate the quality of fracture reduction, four radiographic parameters were used: joint reduction, sagittal alignment, coronal alignment and condylar width. Secondary loss of reduction was characterized as $5^{\circ}$ change in the medial proximal tibial angle and/or slope in the immediate postoperative period and 6 months later.

Parameters were considered satisfactory only if: joint reduction presented a gap or interval of $\leq 2 \mathrm{~mm},{ }^{13,14}$ coronal alignment had a medial proximal tibial angle of $87 \pm 5^{\circ}, 14,15$ sagittal alignment had $9^{\circ} \pm 5^{\circ 16}$ posterior angle of the proximal tibia, ${ }^{6}$ and 0 to $5 \mathrm{~mm}$ condylar width ${ }^{14}$ (Figure 1).

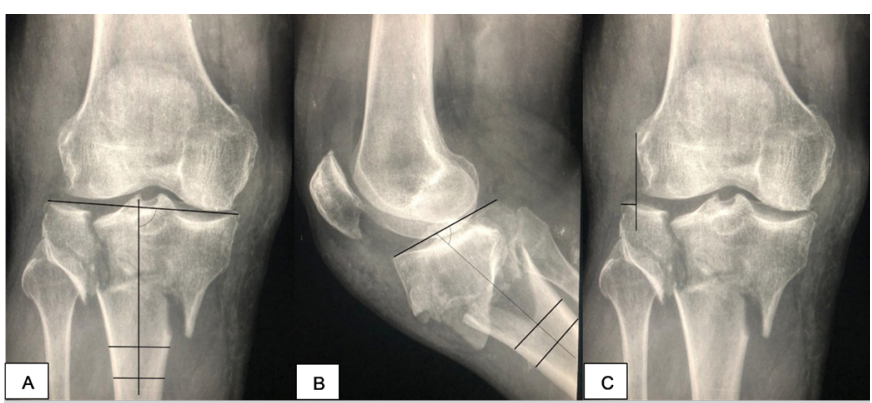

Figure 1. Radiographic measurements.

A: coronal alignment of medial proximal tibial (Slope); B: sagittal alignment of proximal tibial; C: condylar width.
Fixation using double or single lateral locked plate was not randomized. Single lateral locked plate was chosen for indication criteria in the literature: the presence of large and non-marginal medial fragment, medial condyle in bone-contact, lack of fractures in the coronal plane, lack of osteoporosis, and lateral locked plaque availability. ${ }^{6-8}$

Single lateral locked plate osteosynthesis is a surgical technique with anterolateral approach. The incision is based over Gerdy's tubercle, once joint capsule is inserted and ipsilateral meniscus is superiorly folded through its suture, exposing the articular surface. The tibialis anterior muscle and neurovascular bundle are moved aside and protected for surgical follow-up. The double-plate technique is a posteromedial approach parallel to the posteromedial border of the proximal tibia at least $5 \mathrm{~cm}$ distal from the anterolateral incision. The interval between semimembranosus muscles and the medial head of the gastrocnemius was identified. After moved aside from its structures, pes anserinus (goosefoot) was disinserted and then moved aside from the gastrocnemius. If needed, semimembranosus could have been disinserted to expose the posteromedial tibial plateau. Smaller fragments were temporarily stabilized with Kirschner wires, and joint sags greater than $2 \mathrm{~mm}$ were anatomically reduced using fluoroscopy. If needed, autologous cancellous bone graft was used. Final assembly used medial/lateral support plate.

Statistical analysis was performed using Stata 13.0 (StataCorp. 2013. Stata Statistical Software: Release 13. College Station, TX: StataCorp LP). Descriptive statistics for quantitative parameters was performed by calculating mean, standard deviation, mean standard error, median, minimum and maximum values, and sample sizes. Chi-square test was used to compare two distributions of qualitative samples. To compare two groups of quantitative distributions, Student's t test (parametric) was used for samples that may approach normal distribution, whereas Mann-Whitney $U$ test (nonparametric) was used for those that may not. The results were considered statistically significant when $p<0.05$.

\section{RESULTS}

From December 2011 to February 2016, 89 patients underwent surgical treatment for tibial plateau fracture. Of these, fifteen patients were excluded for lacking adequate radiographic documentation, ten for undergoing another osteosynthesis, and one for presenting complications that lead to amputation. From the 63 remaining, 47 were inserted in the double-plate group and 16 in the single lateral locked plate osteosynthesis group.

Table 1 show patient's demographic characteristics according to group. Fractures were classified as types $\mathrm{V}$ and $\mathrm{VI}$, according to the Schatzker classification system, by identifying the mechanisms of injury and whether lesions were closed or exposed.

Table 1. Patient's demographic data according to group.

\begin{tabular}{c|c|c|c}
\hline Parameter & $\begin{array}{c}\text { Double-plate } \\
\text { group (N = 47) }\end{array}$ & $\begin{array}{c}\text { Single lateral } \\
\text { plate group } \\
(\mathrm{N}=16)\end{array}$ & P-value \\
\hline Age (years) & $42.4( \pm 13.70)$ & $46.5( \pm 17.45)$ & 0.340 \\
\hline
\end{tabular}

Double-plate group showed a greater balance regarding the number of patients classified with Schatzker V or VI (44.7 and 55.3\%, respectively) than single lateral plate group (18.75\% Schatzker $V$ and $81.25 \%$ Schatzker VI), with a $p=0.08$.

Patients were also categorized according to mechanism of injury (Table 2), with $p=0.22$, and fracture exposure (Table 3), with $p=0.57$. 
Table 2. Mechanisms of injury.

\begin{tabular}{c|c|c}
\hline Mechanism & $\begin{array}{c}\text { Double-plate } \\
\text { group }(\mathbf{N}=47)\end{array}$ & $\begin{array}{c}\text { Single lateral plate } \\
\text { group }(\mathbf{N}=16)\end{array}$ \\
\hline Motorcycle & $25(53 \%)$ & $7(43.75 \%)$ \\
\hline Motor vehicle & $1(2.1 \%)$ & $0(0 \%)$ \\
\hline Fall at same level & $5(10.6 \%)$ & $0(0 \%)$ \\
\hline Run over & $3(6.4 \%)$ & $4(25 \%)$ \\
\hline Crush & $1(2.1 \%)$ & $0(0 \%)$ \\
\hline Fall from height & $10(21.3 \%)$ & $3(18.75 \%)$ \\
\hline Blunt trauma & $4(4.25 \%)$ & $1(6.25 \%)$ \\
\hline Bicycle & $0(0 \%)$ & $1(6.25 \%)$ \\
\hline
\end{tabular}

Table 3. Exposure of fractures

\begin{tabular}{c|c|c}
\hline Exposed & $\begin{array}{c}\text { Double-plate } \\
\text { group }(\mathrm{N}=47)\end{array}$ & $\begin{array}{c}\text { Single lateral plate } \\
\text { group }(\mathrm{N}=16)\end{array}$ \\
\hline Yes & $8(17.0 \%)$ & $3(18.75 \%)$ \\
\hline No & $39(83 \%)$ & $13(81.25 \%)$ \\
\hline
\end{tabular}

In the immediate postoperative period (Table 4), double-plate group had a higher number of patients with joint step-off (29.8\%) than the single lateral plate group (6.25\%), but without statistical significance ( $p=0.088$ ). Whereas $59.55 \%$ of patients in the double-plate group evolved with joint degeneration in the late postoperative follow-up (Table 5), 31.25\% of single lateral plate group did, without statistical significance $(p=0.275)$.

Table 4. Patient's radiographic data according to group in the immediate postoperative period.

\begin{tabular}{c|c|c|c}
\hline Parameter & $\begin{array}{c}\text { Double-plate } \\
\text { group (N = 47) }\end{array}$ & $\begin{array}{c}\text { Single lateral plate } \\
\text { group (N = 16) }\end{array}$ & P-value \\
\hline Immediate joint step-off & $\begin{array}{c}\text { Yes: } 14(29.8 \%) \\
\text { No: 33\% (70.2) }\end{array}$ & $\begin{array}{c}1(6.25 \%) \\
15(93.75 \%)\end{array}$ & 0.088 \\
\hline Immediate coronal & $88.7( \pm 2.48)$ & $89.2( \pm 2.64)$ & 0.545 \\
\hline Immediate sagittal & $7.2( \pm 4.10)$ & $7,0 \pm 2.94$ & 0.850 \\
\hline Immediate enlargement & $\begin{array}{c}\text { Yes: } 8(17 \%) \\
\text { No: } 39(83 \%)\end{array}$ & $\begin{array}{c}1(6.25 \%) \\
15(93.75 \%)\end{array}$ & 0.275 \\
\hline
\end{tabular}

Table 5. Patient's radiographic data according to group in the late postoperative period.

\begin{tabular}{c|c|c|c}
\hline Parameter & $\begin{array}{c}\text { Double-plate } \\
\text { group (N = 47) }\end{array}$ & $\begin{array}{c}\text { Single lateral plate } \\
\text { group (N = 16) }\end{array}$ & P-value \\
\hline Late joint step-off & $\begin{array}{c}\text { Yes: } 28(59.55 \%) \\
\text { No: } 19(40.45 \%)\end{array}$ & $\begin{array}{c}5(31.25 \%) \\
11(68.75 \%)\end{array}$ & 0.080 \\
\hline Late coronal & $88.8( \pm 3.55)$ & $89.2( \pm 2.46)$ & 0.630 \\
\hline Late sagittal & $7.6( \pm 4.46)$ & $6.6( \pm 4.18)$ & 0.410 \\
\hline Late enlargement & Yes: $11(23.9 \%)$ & $\begin{array}{c}1(6.25 \%) \\
15(93.75 \%)\end{array}$ & 0.123 \\
& Not: $35(76.1 \%)$ & & \\
\hline
\end{tabular}

Immediate enlargement was more frequent within the double-plate group (17\%) than within the single lateral plate group (6.25\%), although without statistical significance, as well as late enlargement ( $p=0.123$ ), and angular measurements in immediate and late coronal and sagittal sections. The double-plate group had a $1.3^{\circ}$ immediate varus and $1.2^{\circ}$ late varus. Tibial slope in the sagittal plane was $7.2^{\circ}$ immediate and $7.6^{\circ}$ late. The single lateral plate group presented a varus of $0.8^{\circ}$ for both immediate and late. Tibial slope in the sagittal plane was $7.0^{\circ} \mathrm{immediate}$ and $6.6^{\circ}$ late.

\section{DISCUSSION}

Fixation with double-plate of Schatzker type $\mathrm{V}$ and $\mathrm{VI}$ fractures is a gold standard procedure. ${ }^{4}$ However, the use of lateral locked plates is gradually spreading and gaining some indications within the literature. Yao et al. ${ }^{6}$ and Weaver et al. ${ }^{8}$ have reached satisfactory results by using it in the presence of tibial condyles in bone-contact, simple trait fractures in the sagittal plane with large and non-marginal medial fragment, and lack of osteoporosis. Furthermore, Yoo et al. ${ }^{17}$ reports the inability of the single lateral locked plate to fix posteromedial fragments, requiring the support of an additional medial plate. ${ }^{17}$ Citak et al. ${ }^{18}$ has also obtained good results in the absence of posteromedial fragments, $33 \%$ of the cases in their series. Jiang et al. ${ }^{11}$ have published a randomized trial of bicondylar tibial plateau fractures, concluding that, despite the greater misalignment found within this group, single lateral plates are an option. Moreover, other studies, 5,9,10 showed better radiographic results, less bleeding, and soft tissue devitalization. Finally, Chang et al. ${ }^{19}$ concluded in a meta-analysis with 559 patients that single lateral locked plate takes less surgical and bonding time, less skin necrosis and higher rate of loss of reduction; other complications and radiographic results showed no statistically significant difference. These studies reproducibility has not yet been widely documented.

There was no randomization in our study. The surgical technique was indicated based on the most favorable procedure to the fracture, considering already published knowledge: presence of large and non-marginal medial fragment, medial condyle in bone-contact, lack of fractures in the coronal plane, lack of osteoporosis, and lateral locked plaque availability. ${ }^{6-8}$

The analyzed radiographic variables (coronal and sagittal alignments, condylar enlargement and joint reduction) showed statistically significant difference between the immediate postoperative period and after six months of follow-up, and the absolute results were satisfactory. Yao et al. ${ }^{6,7}$ obtained the same results using lateral plate for large and non-comminuted medial fragments. These results corroborate lateral locked plate indications. ${ }^{6,8,18}$ The single lateral locked group showed a greater late varus collapse in studies that, unlike the aforementioned, were randomized. ${ }^{10,11}$ However, the joint step-off should be considered a common denominator for both groups studied. Double-plate group had 14 patients (29.5\%) that evolved with loss of anatomical reduction of the joint six months after surgery whereas lateral locked plaque group had four (25\%). This could be justified by the instability caused by joint incongruity with physiological load alterations. Manidakis et al. ${ }^{20}$ report $27.3 \%$ residual varus in the 20 -month follow-up. Neogi et al. ${ }^{10}$ and Jiang et al. ${ }^{11}$ report a greater poor alignment by single lateral locked plate, which is not confirmed in this study.

\section{CONCLUSION}

Despite the reduced sample, this study is aligned with current results published in the medical literature. The severity of Schatzker type $\mathrm{V}$ and $\mathrm{VI}$ tibial plateau fractures can be minimized by the correct indication for the implant. In this context, the use of the single lateral locked plate is a good option in the presence of large and non-marginal medial fragment, medial condyle in bone-contact, lack of fractures in the coronal plane and lack of osteoporosis, whereas the double-plate is still the gold standard for the restoration of cases of complex fragmentation.

Further studies with greater sample, randomization and follow-up periods are needed to confirm this hypothesis. 
AUTHORS' CONTRIBUTIONS: Each author contributed individually and significantly to the development of this article. MMA: data acquisition, data interpretation, writing of the work, final approval of the manuscript version; GHRC: data acquisition, writing; MCL: surgeries, critical review of intellectual content DB: surgeries, conception; JSS: conception, critical review of intellectual content; KEK: conception, surgeries, critical review of intellectual content.

\section{REFERENCES}

1. Moore TM, Patzakis MJ, Harvey JP. Tibial plateau fractures: definition, demographics, treatment rationale, and long-term results of closed traction management or operative reduction. J Orthop Trauma. 1987;1(2):97-119.

2. Schatzker J, McBroom R, Bruce D. The tibial plateau fracture: the Toronto experience 1968-1975. Clin Orthop Relat Res. 1979;(138):94-104.

3. Marsh JL, Slongo TF, Agel J, Broderick JS, Creevey W, DeCoster TA, et al Fracture and dislocation classification compendium - 2007: Orthopaedic Trauma Association classification, database and outcomes committee. J Orthop Trauma. 2007;21(10 Suppl):S1-133.

4. Georgiadis GM. Combined anterior and posterior approaches for complex tibial plateau fractures. J Bone Joint Surg Br. 1994;76(2):285-9.

5. Lee MH, Hsu CJ, Lin KC, Renn JH. Comparison of outcome of unilateral locking plate and dual plating in the treatment of bicondylar tibial plateau fractures. J Orthop Surg Res. 2014;9:62.

6. Yao Y, Lv H, Zan J, Zhang J, Zhu N, Ning R, et al. A comparison of lateral fixation versus dual plating for simple bicondylar fractures. Knee. 2015;22(3):225-9.

7. Yao Y, Lv H, Zan J, Li J, Zhu N, Jing J. Functional outcomes of bicondylar tibial plateau fractures treated with dual buttress plates and risk factors: a case series. Injury. 2014;45(12):1980-4.

8. Weaver MJ, Harris MB, Strom AC, Smith RM, Lhowe D, Zurakowski D, et al. Fracture pattern and fixation type related to loss of reduction in bicondylar tibial plateau fractures. Injury. 2012;43(6):864-9.

9. Lee TC, Huang HT, Lin YC, Chen CH, Cheng YM, Chen JC. Bicondylar tibial plateau fracture treated by open reduction and fixation with unilateral locked plating. Kaohsiung J Med Sci. 2013;29(10):568-77.

10. Neogi DS, Trikha V, Mishra KK, Bandekar SM, Yadav CS. Comparative study of single lateral locked plating versus double plating in type $\mathrm{C}$ bicondylar tibial plateau fractures. Indian J Orthop. 2015;49(2):193-8.
11. Jiang R, Luo CF, Wang MC, Yang TY, Zeng BF. A comparative study of Less Invasive Stabilization System (LISS) fixation and two-incision double plating for the treatment of bicondylar tibial plateau fractures. Knee. 2008;15(2):139-43.

12. Higgins TF, Klatt J, Bachus KN. Biomechanical analysis of bicondylar tibial plateau fixation: how does lateral locking plate fixation compare to dual plate fixation? J Orthop Trauma. 2007;21(5):301-6.

13. Brown TD, Anderson DD, Nepola JV, Singerman RJ, Pedersen DR, Brand RA. Contact stress aberrations following imprecise reduction of simple tibial plateau fractures. J Orthop Res. 1988;6(6):851-62.

14. Honkonen SE. Indications for surgical treatment of tibial condyle fractures. Clin Orthop Relat Res. 1994;(302):199-205

15. Cooke TD, Li J, Scudamore RA. Radiographic assessment of bony contributions to knee deformity. Orthop Clin North Am. 1994;25(3):387-93.

16. Paley D, Herzenberg JE, Tetsworth K, McKie J, Bhave A. Deformity planning for frontal and sagittal plane corrective osteotomies. Orthop Clin North Am. 1994;25(3):425-65.

17. Yoo BJ, Beingessner DM, Barei DP. Stabilization of the posteromedial fragment in bicondylar tibial plateau fractures: a mechanical comparison of locking and nonlocking single and dual plating methods. J Trauma. 2010;69(1):148-55.

18. Citak C, Kayali C, Ozan F, Altay T, Karahan HG, Yamak K. Lateral locked plating or dual plating: a comparison of two methods in simple bicondylar tibial plateau fractures. Clin Orthop Surg. 2019;11(2):151-8.

19. Chang $\mathrm{H}$, Zhu $\mathrm{Y}$, Zheng Z, Chen W, Zhao S, Zhang $\mathrm{Y}$, et al. Meta-analysis shows that highly comminuted bicondylar tibial plateau fractures treated by single lateral locking plate give similar outcomes as dual plate fixation. Int Orthop. 2016;40(10):2129-41.

20. Manidakis N, Dosani A, Dimitriou R, Stengel D, Matthews S, Giannoudis P. Tibial plateau fractures: functional outcome and incidence of osteoarthritis in 125 cases. Int Orthop. 2010;34(4):565-70. 